\title{
ROLE OF PURCHASE DECISION AS A MEDIATION THAT INFLUENCES ATMOSPHERE STORE ON CUSTOMER SATISFACTION
}

\author{
Niode Idris Yanto, Mendo Yusniar, Rauf Fajrunnisa R. \\ Faculty of Economics and Business, Gorontalo State University, Indonesia \\ *E-mail: idrisniode@gmail.com
}

\begin{abstract}
The study was conducted to analyze and determine the effect of the Store Atmosphere on purchasing decisions and customer satisfaction. The sample in this study is the customer of Wong Solo restaurant, Gorontalo City branch. The results showed that (1) Store atmosphere directly had a positive and significant effect on purchasing decisions; (2) Store Atmosphere directly has a positive but not significant effect on customer satisfaction; (3) The purchase decision directly has a positive and significant effect on customer satisfaction; (4) Store Atmosphere indirectly (through purchasing decisions) has a positive and significant effect on customer satisfaction.
\end{abstract}

\section{KEY WORDS}

Store atmosphere, purchasing, decision, satisfaction.

Every company is always trying to be successful in winning every competition with other companies and trying to be able to achieve its goal of creating and retaining customers. Maintaining customers is a challenge for companies that must be pursued for the survival of the company. In the selection and purchase of a product, consumers are much influenced by other factors that encourage consumers to make purchasing decisions, because purchasing decisions are the hope of every company.

The purchasing decision is a decision chosen by someone in determining or considering one of several alternative options offered. This is as revealed by Kotler and Armstrong (2008) purchasing decisions are the stages in the purchasing decision process where consumers actually buy. Purchasing decision making is an activity in which individuals is directly involved in obtaining and using the goods or services offered.

Price, quality, and service are no longer the main consideration for culinary connoisseurs, now the atmosphere is an important factor for a consumer in choosing where to eat. A comforTable and homey atmosphere becomes a material consideration for consumers before deciding to come or visit certain restaurants. Not a few consumers who prefer to eat in a restaurant rather than eating at home with a reason to like the atmosphere (atmosphere) at the restaurant in question.

One way to win the competition is to make something different. Store atmosphere can be an alternative to differentiate one restaurant from another. Differences are needed because from every business, certain products are found with prices that range from even slightly different. Store atmosphere can be more reason for consumers to be interested and choose where they will visit and buy. This is as said by Utami (2008) that the atmosphere is a combination of physical characteristics, such as architecture, layout, lighting, color, temperature, music, and aroma which aim to design emotional responses and customer perceptions and to influence customers in buying products.

Store atmosphere not only affects purchasing decisions but also affects customer satisfaction. Although all the determinants of customer satisfaction need to be considered in research and practice, for the most part, the atmosphere may determine the overall level of satisfaction in the restaurant and café industry. A store atmosphere is a combination of emotional things. According to Mowen and Minor (2012) store atmosphere affects the emotional state of customers, which then encourages increasing or reducing purchases. The impact of the store atmosphere can create the impression that consumers will increase their purchases or just buy enough and may not intend to go back again to buy at that place. The 
impression obtained has an impact on customer satisfaction. Producers must be observant in seeing market opportunities and the desires and needs of customers to be able to provide satisfaction to customers so as not to turn to competitors.

Based on the description above, the writer is interested to know in more detail about the influence of Store Atmosphere on purchasing decisions and customer satisfaction. The author chose Wong Solo Branch of Gorontalo City as a place to conduct research, because this restaurant does not only sell a variety of foods and beverages, is strategically located, and can create a comforTable atmosphere with a good place design that provides a special attraction for consumers or potential customers. Site selection is also based on the ease of access to data and the collection of data in research.

\section{LITERATURE REVIEW}

The store atmosphere is the status of affection and cognition that is understood by consumers in a restaurant, although it may not be fully realized by consumers when shopping (Sutisna \& Pawitra, 2001). A store atmosphere is a combination of planned physical messages. According to Foster (2008). Store atmosphere can be described as a change in environmental planning, purchases that produce special emotional effects that can cause consumers to make purchases.

The store atmosphere has elements that affect the atmosphere of the restaurant created. This study refers to the theory of Berman and Evans (2010) because the elements of the atmosphere can be operationalized in restaurants or cafes as objects in this study. Berman and Evans mention that the atmosphere element consists of:

- Exterior (shop front). The exterior of a store has a strong influence on the store's image and must be planned carefully. Consumers sometimes judge a store from its front. The front of a store is the entire physical exterior of a store. Included in the exterior are entrances, storefronts, patios, shop signs, other construction materials;

- General Interior. When consumers are in a shop, many elements influence their perception. Bright lights, sounds, and aromas that can affect the feelings of consumers as well as store equipment such as shelves, storefronts that can be planned based on their usefulness and aesthetics;

- Store layout (layout). Includes structuring the placement of space to fill available floor sections, classifying products to be offered, managing traffic in the shop. The division of store space includes rooms: Selling space or sales space, Merchandise space or merchandise space, Personnel space or employee space which is a special room for the employees, Customer space or space for consumers;

- Interior (point-of-purchased) displays. These are the signs used to provide information to consumers. The indicators used are posters, signs, special event pictures, and wrapping media.

The purchase decision is a selection made on two or more choices (Schiffman \& Kanuk, 2008). A consumer who wants to make a choice then he must have a choice. For consumers, the purchasing decision process is an important activity because in the process contains various steps that occur sequentially before the consumer makes a decision. Complicated decision-making processes often involve several decisions; a decision involves a choice between two or more alternative actions. Decisions always require a choice between several different behaviors (Setiadi, 2013).

According to Kotler (2009), satisfaction is someone's happy or disappointed feelings that arise after comparing perceptions or impressions on the performance or results of a product and its expectations. This opinion is the same as stated by Tjiptono and Chandra (2016) which states that customer satisfaction or dissatisfaction is the response given to the evaluation of the perceived discrepancy between previous expectations and the actual performance of the product after its use so that it can be said if the performance is below expectations, the customer will feel unsatisfied. So satisfaction is a function of perception or impression of performance and expectations. If the performance is below expectations, the 
customer is not satisfied. If the performance exceeds expectations, the customer will be very satisfied or happy.

Westbrook and Raeilli in Tjiptono (2014) argue that consumer satisfaction is an emotional response to experiences relating to certain products or services purchased, retail outlets, or even behavior patterns (such as shopping behavior and buying behavior) and the overall market. Emotional responses are triggered by cognitive evaluation processes that compare perceptions or beliefs about individual objects, actions (or conditions with the values of needs, and desires) of individuals.

There are several methods that each company can use to measure and monitor the satisfaction of its customers and competing customers as stated by Kotler cited in (Tjiptono, 2014). Kotler (2009) defines four methods for measuring customer satisfaction, including:

- System of complaints and suggestions;

- Ghost Shopping (mystery Shopping);

- Run customer analysis;

- Customer satisfaction survey.

Besides, Tjiptono (2014) states that consumer satisfaction has the following indicators:

- Feeling happy consumers;

- The desire to make repeat purchases;

- Recommend to others;

- Consumers have a positive memory for the company.

\section{METHODS OF RESEARCH}

The variables in this study consisted of two variables, namely the Store Atmosphere (X1) independent variable with 4 indicators: Exterior, General Interior, Store Layout, Interior Display. Purchase decision (X2) with 5 indicators, namely: Identification of Needs, Information Search, Alternative Evaluation, Purchase Decision, Post-Purchase Behavior. And the dependent variable Customer satisfaction $(\mathrm{Y})$ is lowered into 4 indicators, namely: Feelings of happy consumers, the desire to make repeat purchases, Recommend to others, Consumers have positive memories of the company.

The samples used in this study were 67 visitors to the Wong Solo Restaurant Branch in Gorontalo City. The technique used in this study is non-probability sampling, where all elements in the population do not have the same opportunity to be selected as a sample (Ferdinand, 2006). This is done because, given the limited time available, the sampling method uses accidental sampling and convenience sampling.

\section{RESULTS AND DISCUSSION}

The results of testing the hypothesis of the influence of Store Atmosphere on purchasing decisions at Wong Solo restaurant, Gorontalo City Branch are presented below:

Table 1 - Store Atmosphere Test Results on Customer Satisfaction

\begin{tabular}{lcc}
\hline \multicolumn{1}{c}{ Model } & (Constant) & Store Atmosphere \\
\hline Value Coefficient (t-Count) & 4.397 & 1.164 \\
Significance & 0,000 & 0.249 \\
$\mathrm{~T}_{\text {table }}$ & & 1,996 \\
Information & & No significant effect \\
\hline
\end{tabular}

The analysis results above show that the t-count value for the Store Atmosphere variable was obtained at 1.164 while the t-Table value was at a significance level of $5 \%$ and the degree of free $n-k-1$ or $67-2-1=64$ was 1.998 . If the two t-values are compared then the $\mathrm{t}$-count value is still smaller than the $\mathrm{t}-\mathrm{Table}$ value $(1.164<1.996)$. So that at $95 \%$ confidence level Store Atmosphere has a positive but not significant effect on customer satisfaction at Wong Solo Restaurant Branch in Gorontalo City. 
Descriptive results regarding customer satisfaction found that customer satisfaction lies in the criteria that are "satisfied" with a score of $80.00 \%$. So it can be said that customers feel a high level of satisfaction with the Gorontalo City Wong Solo Restaurant Branch which will encourage customers to become loyal customers. Satisfaction is achieved when quality meets and exceeds the expectations, desires, and needs of consumers. Conversely, if the quality does not meet and exceed the expectations, desires, and needs of consumers, satisfaction is not achieved. Consumers who are not satisfied with the goods or services they consume will look for other companies that can provide their needs. This result is supported by the results of research by Nur Aina Abdul Jalil et al (2015), and Rahman (2015) were the results found that there is a significant effect of Store Image on Customer Satisfaction.

The results of testing the hypothesis of the influence of purchasing decisions on customer satisfaction in the Wong Solo restaurant, Gorontalo City Branch are presented below:

Table 2 - Purchase Decision Test Results on Customer Satisfaction

\begin{tabular}{lcc}
\hline \multicolumn{1}{c}{ Model } & (Constant) & Buying decision \\
\hline Value Coefficient (t-Count) & 4.397 & 5.793 \\
Significance & 0,000 & 0,000 \\
$\mathrm{~T}_{\text {table }}$ & & 1,996 \\
Information & & Significant effect \\
\hline
\end{tabular}

The analysis results above show that the t-count value for the purchase decision variable is 5.793 while the t-Table value is at a significance level of $5 \%$ and the degree of freedom $n-k-1$ or $67-2-1=64$ is 1.998 . If the two t-values are compared then the $t$-count value is still greater than the $\mathrm{t}$-Table value (5.793> 1.996). So that the $95 \%$ confidence level of purchasing decisions has a positive and significant effect on customer satisfaction at Wong Solo Restaurant, Gorontalo City Branch.

Descriptive results regarding purchasing decisions found that by $83.91 \%$ the score of respondents' answers to the purchase decision which means it lies in the criteria of "good". This shows that the customers of Gorontalo City Wong Solo Restaurant Branch have decision stages in making an appropriate purchase which means the products sold by the Gorontalo City Wong Solo Restaurant Branch are following the tastes and desires of consumers or customers. The results of the study were supported by research conducted by Susanto. (2013); Saputra et al (2017) where the results of the study prove that purchasing decisions affect consumer satisfaction.

From the results of simultaneous testing, the F-count value of this study was 23.742 . Meanwhile, the value of $F$ Table at a significance level of $5 \%$ and df 1 of $k=2$ and df 2 of $N-k$ $1=67-2-1=64$ is 3.140 . If both the F value is compared, then the F-count value is greater than the value of the F-Table thus Store Atmosphere and purchase decisions jointly significant effect on customer satisfaction in the House of Wong Solo meal Branch of Gorontalo.

Table 3 - Simultaneous Testing Results

\begin{tabular}{lclccc}
\hline Model & Sum of Squares & df & Mean Square & F & Sig. \\
\hline Regression & 588.278 & 2 & 294.139 & 23.742 & $000^{\mathrm{b}}$ \\
Residual & 792.897 & 64 & 12.389 & & \\
Total & 1381.176 & 66 & & & \\
\hline
\end{tabular}

In path analysis, the correlation coefficient $(r)$ is needed in the calculation of path analysis (Path Analysis). The results of correlation analysis ( $r$ ) testing with the help of SPSS 21 presented in Table 4.

Based on the results of the correlation coefficient analysis above, it can be seen the correlation between Store Atmosphere with a purchasing decision of 0.392 then the Store Atmosphere variable with customer satisfaction of 0.353 , and the correlation of purchasing decisions with customers satisfaction of 0.643 . 
Table 4 - Correlation Coefficients

\begin{tabular}{ccccc}
\hline & & Customer satisfaction Store Atmosphere & Buying decision \\
\hline \multirow{3}{*}{ Pearson Correlation } & Customer satisfaction & 1.000 & .353 & .643 \\
& Store Atmosphere & .353 & 1.000 & .392 \\
& Buying decision & .643 & .392 & 1.000 \\
& Customer satisfaction &. & .002 & .000 \\
Sig. (1-tailed) & Store Atmosphere & .002 & .001 \\
& Buying decision & .000 & .001 & .001 \\
& Customer satisfaction & 67 & 67 & 67 \\
& Store Atmosphere & 67 & 67 & 67 \\
& Buying decision & 67 & 67 & 67 \\
\hline
\end{tabular}

Based on the framework of thought and steps in path analysis according to Hartono (2012), the empirical causal framework between paths (Store Atmosphere and Purchasing Decisions on Customer Satisfaction) through the structural equation is as follows:

$$
\begin{gathered}
\hat{Y}(\text { Buying decision })=0,392 \mathrm{X}_{1}+\mathrm{e} \\
\hat{\mathrm{Y}}(\text { Customer satisfaction })=0,120 \mathrm{X}_{1}+0,596 \mathrm{X}_{2}+\mathrm{e}
\end{gathered}
$$

So that it can be described the coefficient which states the determination of the total $\mathrm{X} 1, \mathrm{X} 2$ against $\mathrm{Y}$ or $\mathrm{R} 2 \mathrm{y}(\mathrm{X} 1, \mathrm{X} 2)$ is as follows:

$$
\begin{gathered}
R^{2} y_{(X 1, X 2)}=(0,120.0,596)\left[\begin{array}{l}
0,353 \\
0,643
\end{array}\right] \\
R^{2} y_{(X 1, X 2)}=(0.042+0.384) \\
R^{2} y_{(x 1, x 2)}=0,426 \text { (Multiple Determination) } \\
P_{y} \varepsilon=1-0,426=0,574 \text { (Influence of other variables) }
\end{gathered}
$$

Based on the Table above, it can be described as the path structure of variables $\mathrm{X} 1$ and $\mathrm{X} 2$ concerning $\mathrm{Y}$ below:

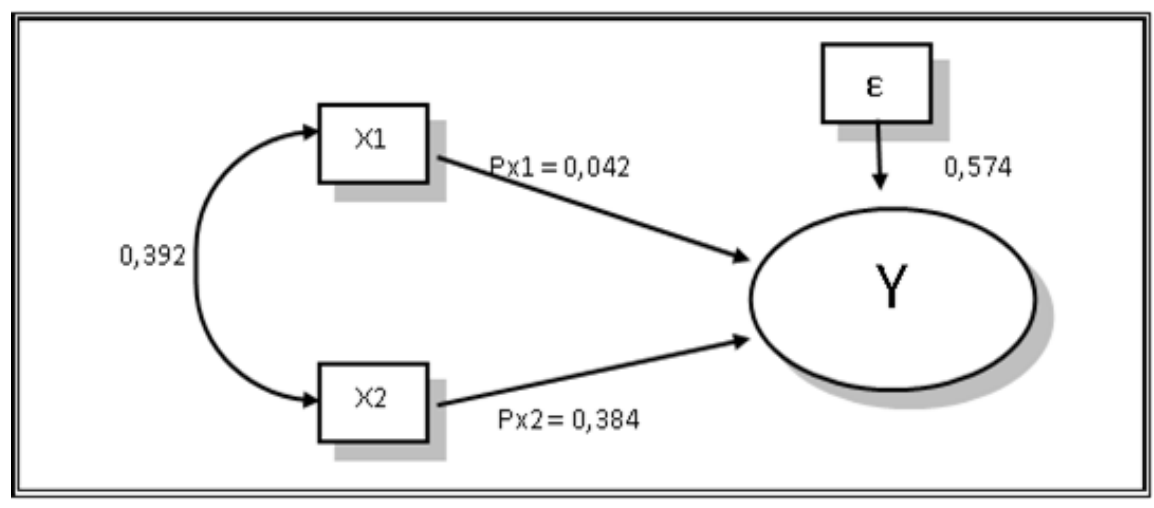

Figure 1 - Chart of Research Path Analysis

In addition to the calculation method above, it can also be done with the formula (Ghozali, 2013) that in the path analysis there are three terms known for the contribution of the influence of the test namely Direct Causal Effect, Indirect Causal Effect and Total Influence. The standardized coefficient of the regression test above will provide an overview of the effect of each independent variable on the dependent variable and the effect of the independent variable on the mediating variable.

The results of the direct influence, not directly and the total effect of the Store Atmosphere on customer satisfaction at the Wong Solo restaurant Gorontalo City Branch are presented in Table 5.

The results of the influence directly, not directly and the total influence of the purchase decision on customer satisfaction at the Wong Solo restaurant Gorontalo City Branch is presented in Table 6. 
Table 5 - Effects of $\mathrm{X} 1$ on $\mathrm{Y}$

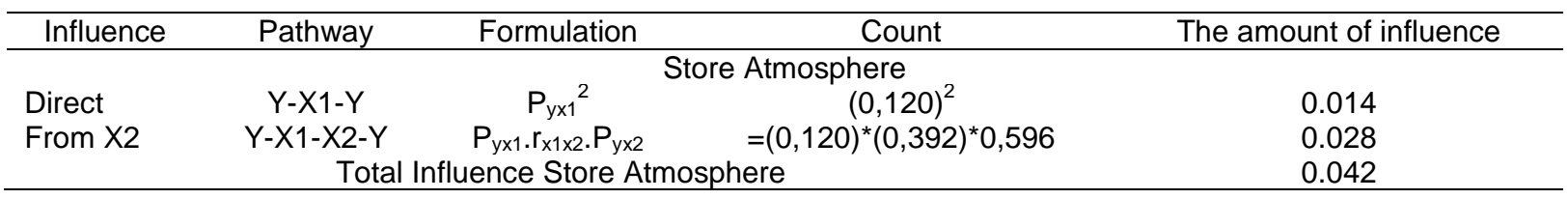

Table 6 - Effects of $\mathrm{X} 2$ on $\mathrm{Y}$

\begin{tabular}{ccccc}
\hline Influence & Pathway & Formulation & Count & The amount of influence \\
\hline & & Buying decision & \\
Langsung & $Y-X 2-Y$ & $P_{y \times 2} 2^{2}$ & $(0,596)^{2}$ & 0.356 \\
Melalui X1 & $Y-X 2-X 1-Y$ & $P_{y \times 2} \cdot r_{\times 2 \times 1} \cdot P_{y \times 1}$ & $0,596^{*}(0,392)^{*}(0,120)$ & 0.028 \\
& Total Influence Buying decision & 0.384 \\
\hline
\end{tabular}

Based on the calculations and analysis above, the effect of each of the following tests can be shown:

Table 7 - Direct and Indirect Influence Pathways and Total Influences

\begin{tabular}{llc}
\hline \multicolumn{1}{c}{ Variable } & \multicolumn{1}{c}{ Influence } & The amount of influence \\
\hline & Direct & 0.014 \\
Store Atmosphere & FormX2 & 0.028 \\
& Total X1 & 0.042 \\
& Direct & 0.356 \\
Buying decision & From X1 & 0.028 \\
& Total X2 & 0.384 \\
Influence X1 to X2 & & 0.392 \\
Determination Multiplier (Total X1+X2) & & 0.426 \\
Influence of Other Variables & & 0.574 \\
\hline
\end{tabular}
below:

Furthermore, mediation hypothesis testing can be done with the Sobel test presented

$$
\begin{gathered}
S a b=\sqrt{b^{2} \cdot S a^{2}+a^{2} \cdot S b^{2}+S a^{2} \cdot S b^{2}} \\
S a b=\sqrt{0,532^{2} \cdot 0,115^{2}+0,396^{2} \cdot 0,092^{2}+} 0,115^{2} \cdot 0,092^{2} \\
S a b=0.0721094
\end{gathered}
$$

To test the significance of the influence for the indirect influence between Store Atmosphere variables on customer satisfaction through the purchase decision can be known by calculating the $z$ Table value with the following formula:

$$
\begin{gathered}
Z_{\text {Hitung }}=\frac{a b}{\text { Sab }}=2,921 \\
\text { Probability } Z_{\text {Hitung }}=0,002
\end{gathered}
$$

Based on the calculation above it can be seen the value of the Z-count equal to 2.921 with a significance of 0.002 . This result is smaller than the value of 0.05 . So it can be concluded that $\mathrm{H} 4$ is accepted or in other words, it can be concluded that there is a significant influence of the Store Atmosphere indirectly (through purchasing decisions) on customer satisfaction at Wong Solo Restaurant, Gorontalo City Branch.

\section{CONCLUSION}

Based on the results of research and discussion, the following research conclusions can be drawn:

- Store Atmosphere directly has a positive and significant effect on purchasing decisions at Wong Solo Restaurant, Gorontalo City Branch;

- Store Atmosphere directly has a positive but not significant effect on customer satisfaction at Wong Solo Restaurant, Gorontalo City Branch; 
- The purchase decision directly has a positive and significant effect on customer satisfaction at Wong Solo Restaurant, Gorontalo City Branch;

- Store Atmosphere indirectly (through purchasing decisions) has a positive and significant effect on customer satisfaction at Wong Solo Restaurant, Gorontalo City Branch. This significant direct result shows that the purchasing decision variable can be a good mediating variable to increase the influence of the store atmosphere on customer satisfaction.

\section{REFERENCES}

1. Alma, B. (2011). Manajemen Pemasaran and Pemasaran Jasa. Bandung: Alfabeta.

2. Amirullah. (2002). Perilaku Konsumen. Yogyakarta: Graha IImu.

3. Susanto. Andhika H. 2013. The influence of customer purchase decision on customer satisfaction and it's impact to customer loyalty. Journal EMBA. Vol.1 No.4 Desember 2013, Hal. 1659-1666.

4. Berman and Evans, 2010. "Retail Management". 12th Edition. Jakarta; Pearson.

5. Dharmmesta, B., \& Handoko, H. T. (2011). Manajemen Pemasaran; Analisis Perilaku Konsumen Jilid 2. Jakarta: PT. Binarupa Aksara.

6. Ferdinand, A. (2006). Metode Penelitian Manajemen: Pedoman Penelitian untuk Skripsi, Tesis and Disertasi IImu Manajemen . Semarang: Universitas Diponegoro.

7. Foster. B. 2008. "Manajemen Ritel". Alfabeta, Bandung.

8. Ghozali. I. 2013. Aplikasi Analisis Multivariate dengan Program SPSS. Edisi Ketujuh. Semarang. Badan Penerbit Universitas Diponegoro.

9. Hartono. H. (2012). Pengaruh Display, Kepercayaan Merek, Keakraban Merek, Persepsi, Harga Terhadap Intensi Pembelian and Pembelian Tak Terencana. Jurnal Ekonomika Bisnis Universitas Kristen Satya Wacana, and 1 (1), 1-22.

10. Irawan, J. H. (2008). Sepuluh Prinsip Kepuasan Pelanggan. Jakarta: Media Komputindo Kelompok Gramedia.

11. Juharsah and Hartini. (2019). The Influence of The Store Atmosphere on Purchasing Decisions on Consumers of Mini Markets in The City of Kendari. IOSR Journal of Business and Management (IOSR-JBM). Volume 21, Issue 6. Ser. V (June. 2019), PP 94-99.

12. Kotler, \& Amstrong. (2008). Prinsip-prinsip Pemasaran, Jilid 1 \& 2 Edisi 12. Jakarta: Erlangga.

13. Kotler, K. (2009). Manajemen Pemasaran 1.Edisi ketiga belas. Jakarta: Erlangga.

14. Maretha, J., \& Kuncoro, A. (2005). Store Atmosphere Dalam Pemasaran. Seoul: Abrakadabra.

15. Mowen, John C and Minor, Micheal. (2012). Perilaku Konsumen dialih bahasakan oleh Dwi Kartika Yahya. Jakarta: Erlangga.

16. Nur Aina Abdul Jalil, Amily Fikry and Anizah Zainuddin (2015). The Impact of Store Atmospherics, Perceived Value, and Customer Satisfaction on Behavioural Intention. Fifth International Conference On Marketing And Retailing (5TH INCOMaR) 2015. Procedia Economics and Finance 37 (2016) 538-544.

17. Octaviani, A. (2014). Pengaruh Store Atmosphere Terhadap Keputusan Pembelian Konsumen Coffe Toffe Jatim Expo Surabaya. Jurnal Fakultas Ekonomi Kampus Ketintang Surabaya.

18. Putri, L. H., Kumadji, S., \& Kusumawati, A. (2014). Pengaruh Store Atmosphere Terhadap Keputusan Pembelian and Kepuasan Pelanggan (Studi pada Monopoli Cafe and Resto Soekarno Hatta Malang). Jurnal Administrasi Bisnis (JAB)|Vol. 15 No. 2 Oktober 2014.

19. Rahman. H. 2015. Skripsi - Pengaruh Store Image Terhadap Kepuasan Pelanggan Pada Pt. Karsa Utama Gorontalo. Universitas Negeri Gorontalo.

20. Santoso, S. (2012). Statistik Parametik. Jakarta: PT. Gramedia Pustaka Umum.

21. Setiadi. Nugroho J. 2013. Perilaku Konsumen (edisi revisi). Jakarta: Kencana Perdana Media Grup 
22. Schiffman, L., \& Kanuk, L. L. (2008). Perilaku Konsumen. Alih Bahasa: Zoelkifli Kasip. Edisi Ketujuh. Cetakan Keempat. Jakarta: PT. Indeks.

23. Sutisna and Pawitra and Pawitra. (2001), Perilaku Konsumen and Komunikasi Pemasaran. PT. Remaja Rosdakarya, Bandung

24. Saputra. S. T. Hidayat. K., \& Sunarti. 2017. Pengaruh Kualitas Produk Terhadap Keputusan Pembelian and Dampaknya Terhadap Kepuasan Konsumen Pengguna Iphone. Jurnal Administrasi Bisnis (JA)

25. Fandy Tjiptono and Gregorius chandra. 2016. Service, Quality \& satisfaction. Yogyakarta. Andi.

26. Fandy Tjiptono. 2014 Pemasaran Jasa. Gramedia.

27. Utami, C.W. 2008. Manajemen Riset (Strategi and Implementasi Ritel Modern). Jakarta. Salemba Empat. 